\title{
Wartość macierzyństwa jako wymiar poczucia szczęścia bezdomnych kobiet
}

\section{Wstęp}

W problematyce związanej z szeroko ujmowaną aksjologią dotyczącą kategorii osób doświadczających bezdomności obecna jest spora luka badawcza. Warto podkreślić, że wśród dostępnych wyników badań dotyczących bezdomnych kobiet żadne nie uwzględniają obszaru wartości, jakie niesie za sobą macierzyństwo. Pomija się zatem to, co dla osób bezdomnych jest wartością, a - co pragnę podkreślić - świadomość tego, co tę wartość (lub wartości) stanowi, może być, po pierwsze, niezwykle przydatna w kontekście rozumienia tego, co dla osób w tym szczególnie trudnym położeniu społecznym jest wpisane w sens życia, po drugie natomiast może być pomocna w zakresie budowania praktycznych strategii, mających na celu prewencję i minimalizację zjawiska bezdomności.

\section{Bezdomność kobiet i jej specyfika}

Bezdomność jest przykładem skrajnego wykluczenia społecznego. Ekskluzja społeczna osób bezdomnych obejmuje wymiar społeczny, zawodowy, kulturowy i prawny. Zjawisko to analizowane jest zarówno $\mathrm{w}$ aspekcie socjologicznym, który uwzględnia złożoność tego problemu społecznego, jak i w kontekście indy-

* Mgr Małgorzata Piechowicz-Bogaczyk - Zakład Patologii Społecznej i Resocjalizacji, Instytut Pedagogiki, Wydział Nauk Społecznych, Uniwersytet Gdański, e-mail: malgorzata.piechowicz@ ug.edu.pl, ORCID: 0000-0003-3456-7286.

1 D. Piekut-Brodzka, O bezdomnych i bezdomności. Aspekty fenomenologiczne, etiologiczne, terapeutyczne, Chrześcijańska Akademia Teologiczna, Warszawa 2000, s. 70; I. Kaźmierczak-Kałużna, 
widualnym, który przede wszystkim akcentuje deficyty osób doświadczających bezdomności. W tym miejscu należy podkreślić, że bezdomne kobiety stanowią zdecydowaną mniejszość na tle całej populacji osób bezdomnych w Polsce. Badania wskazują bowiem, że bezdomnych kobiet jest około $30 \%{ }^{2}$. Na podstawie analizy literatury przedmiotu można zbudować syntetyczny obraz „kobiecej” bezdomności, uwzględniając psychospołeczny aspekt ich funkcjonowania:

1. Bezdomne kobiety zazwyczaj są samotnymi matkami³.

2. Bezdomne kobiety mieszkają w schroniskach dla osób bezdomnych; stanowią zatem mały odsetek tzw. „bezdomności ulicznej”".

3. Bezdomne kobiety nie są wyposażone w wystarczające kompetencje rodzicielskie ${ }^{5}$.

4. Bezdomne kobiety charakteryzują się zewnętrznym umiejscowieniem poczucia kontroli, co wiąże się z brakiem długofalowych celów życiowych oraz deficytami w zakresie zaradności życiowej.

5. Bezdomne kobiety wywodzą się z rodzin patologicznych, w których funkcjonowanie wpisana jest przemoc oraz uzależnienia ${ }^{7}$.

Bezdomność jako forma wykluczenia społecznego w świetle wybranych aktów prawnych oraz dokumentów strategicznych i programowych, „Opuscula Sociologica” 2015, nr 2, s. 1936.

2 A. Przymeński, Bezdomność jako kwestia społeczna w Polsce współczesnej, Wydawnictwo Akademii Ekonomicznej w Poznaniu, Poznań 2001; B. Szluz, Świat społeczny bezdomnych kobiet, Bonus Liber, Warszawa 2010, s. 96; M. Dębski, Sytuacja społeczna bezdomnych kobiet w województwie pomorskim, w: Forum. O bezdomności bez lęku, red. Ł. Browarczyk, Pomorskie Forum na Rzecz Wychodzenia z Bezdomności, Gdańsk 2008, s. 11-106.

${ }^{3}$ M. Mikołajczyk, Rodziny bezdomnych matek. Charakterystyka i działania pomocowe, Wydawnictwo Akademii Pedagogiki Specjalnej, Warszawa 2018, s. 25 i 155; M. Piechowicz, Specyfika funkcjonowania bezdomnych rodzin na przykładzie bezdomnych kobiet z dziećmi w Gdańsku, w: Rodzina wobec problemów i wyzwań wspótczesności. W poszukiwaniu rozwiązań, red. B. Chrostowska, M. Dymowska, M. Zmysłowska, t. 2, Wydawnictwo Uniwersytetu Warmińsko-Mazurskiego w Olsztynie, Olsztyn 2015, s. 171-180.

${ }^{4}$ M. Dębski, A. Michalska, Podręcznik streetworkera bezdomności, Pomorskie Forum Na Rzecz Wychodzenia z Bezdomności, Gdańsk 2012, s. 70; J. Bielecka-Prus, Sytuacja życiowa osób bezdomnych, w: Społeczne i instytucjonalne aspekty bezdomności na Lubelszczyźnie, red. J. Bielecka-Prus, P. Rydzewski, R. Maciejewska, Wydawnictwo WSPA, Lublin 2011, s. 21; B. Szluz, Świat społeczny..., s. 14.

${ }^{5}$ J. Bielecka-Prus, Sytuacja życiowa osób bezdomnych, s. 11-30; A. Azim, H. MacGillvray, D. Heise, Mothering in the Margin: a Narrative Inquiry of Women with Children in a Homeless Shelter, „Journal of Social Distress and The Homeless" 2019, t. 28, nr 1, s. 34-43; D. David, L. Gelberg, N.E. Suchman, Implications of Homelessness for Parenting Young Children: a Preliminary Review from a Developmental Attachment Perspective, „Infant Mental Health Journal” 2012, t. 33, nr 1, s. 1-9; B. Szluz, Świat społeczny..., s. 338.

${ }^{6}$ H. Kubicka, Bezdomność rodzin samotnych matek. Społeczno-wychowawcze aspekty zjawiska, Wydawnictwo Uniwersytetu Łódzkiego, Łódź 2005, s. 110; B. Szluz, Świat społeczny..., s. 329; A. Sucharska-Daraż, Kryzys w wartościowaniu a postawy życiowe bezdomnych kobiet, w: Osoby bezdomne. Psychologiczne aspekty ich funkcjonowania, red. M.A. Basińska, Fundacja Salvus, Bydgoszcz 2014, s. 191-221; M. Piechowicz, Specyfika funkcjonowania bezdomnych..., s. 171-180.

7 B. Szluz, Świat społeczny..., s. 121; M. Mikołajczyk, Rodziny bezdomnych..., s. 170. 
To, co tworzy powyższy profil, niewątpliwie łączy się z uwarunkowaniami przyczyn bezdomności kobiet. Oczywistym jest fakt, że bardzo rzadko osoba staje się bezdomną z dnia na dzień. Zazwyczaj bowiem proces popadania w bezdomność determinowany jest konglomeratem przyczyn, które najczęściej współwystępują. Analiza badań w tym zakresie pozwala wyróżnić następujące kategorie uwarunkowań bezdomności kobiet:

1. Obejmujące dysfunkcjonalność rodziny ${ }^{8}$

2. Obejmujące uzależnienia i cechy psychopatologiczne ${ }^{9}$

3. Obejmujące problemy mieszkaniowe ${ }^{10}$.

Warto zasygnalizować, że świadomość tego, jakie okoliczności, cechy i sytuacje stanowią predyktory bezdomności kobiet, może się przyczynić do profesjonalizacji zarówno działań interwencyjnych, jak i profilaktycznych skierowanych do tej kategorii społecznej.

\section{Macierzyństwo jako wartość}

Macierzyństwo to zagadnienie będące przedmiotem zainteresowań nie tylko nauk społecznych, lecz także teologicznych, prawnych oraz medycznych. Niewątpliwie, wraz ze zmianami demograficznymi i kulturowymi w Polsce,

${ }^{8}$ M. Tyl, Dysfunkcjonalność rodziny a bezdomność, „Praca Socjalna” 2005, nr 1, s. 46-59; K. Swick, Responding to the Voices of Homeless Preschool Children and Their Families, „Early Childhood Education Journal" 2010, t. 38, nr 4, s. 299-304; R. Maciejewska, J. Bielecka-Prus, Problemy $w$ funkcjonowaniu instytucji działajacych na rzecz pomocy osobom bezdomnym, w: Społeczne i instytucjonalne aspekty bezdomności na Lubelszczyźnie, red. J. Bielecka-Prus, P. Rydzewski, R. Maciejewska, Wydawnictwo WSPA, Lublin 2011, s. 201-229; L. Whitbeck, B. Armenta, M. Welch-Lazoritz, Borderline Personality Disorder and Axis I Psychiatric and Substance Use Disorders Among Women Experiencing Homelessness in Three US Cities, „Social Psychiatry and Psychiatric Epidemiology” 2015, t. 50, nr 8, s. 1285-1291; M. Phipps, L. Dalton, H. Maxwell i in., Women and Homelessness, a Complex Multidimensional Issue: Findings From a Scoping Review, „Journal of Social Distress and The Homeless" 2019, t. 28, nr 1, s. 1-13.

9 P. Hanrahan, M. McCoy, L. Cloninger i in., The Mothers' Project for Homeless Mothers with Mental Illnesses and Their Children: A Pilot Study, „Psychiatric Rehabilitation Journal” 2005, t. 28, nr 3, s. 291-294; H. Kubicka, Bezdomność rodzin samotnych matek..., s. 89; B. Szluz, Świat społeczny..., s. 333; R. Maciejewska, J. Bielecka-Prus, Problemy w funkcjonowaniu instytucji..., s. 201-229; C. Upshur, D. Jenkins, L. Weinreb i in., Prevalence and Predictors of Substance Use Disorders Among Homeless Women Seeking Primary Care: An 11 Site Survey: Prevalence and Predictors of Homeless Women's Alcohol and Drug use Disorders, „The American Journal on Addictions” 2017, t. 26, nr 7 , s. 680-688; M. Roze, J. ven der Wearden, M. Melchior i in., Factors Associated with Depression Among Homeless Mothers. Results of the ENFAMS Survey, "Journal od Affective Disorders" 2018, t. 229 , s. 314-321.

${ }^{10}$ H. Kubicka, Bezdomność rodzin samotnych matek..., s. 128; B. Szluz, Świat społeczny..., s. 330; M. Piechowicz, Specyfika funkcjonowania bezdomnych..., s. 171-180; M. Phipps, L. Dalton, H. Maxwell, M. Cleary, Women and homelessness..., s. 1-13. 
problematyka macierzyństwa istotnie wpisała się w dyskurs aksjologiczny. Niezależnie jednak od przyjętej perspektywy, „macierzyństwo jako proces stawania się i bycia matką bezspornie jest wartością ponadczasową; jest istotnym procesem rozwoju w życiu kobiety, dziecka, mężczyzny - w życiu całej rodziny. Macierzyństwo jest ważnym czynnikiem w kształtowaniu się osobowości wszystkich jej członków"11.

Definiując macierzyństwo, można odwołać się do prawno-formalnego ujęcia tego pojęcia. Przez macierzyństwo rozumie się stosunek prawny łączący kobietę i jej dziecko ${ }^{12}$. Warto podkreślić, że „macierzyństwo, jako stosunek związany z pochodzeniem dziecka od określonej kobiety jest podstawowym stosunkiem rodzinnym, wiążącym się z powstaniem instytucji społecznej - rodziny"13. $\mathrm{W}$ wymiarze psychospołecznym macierzyństwo definiowane jest jako „proces stawania się i bycia matką"14. Niewątpliwie „macierzyństwo stanowi w naszej kulturze wartość niekwestionowaną"15.

Warto w tym miejscu zastanowić się nad zagadnieniem pojęcia „wartości”. Spośród wielu socjologicznych definicji tego pojęcia, zasadna - z punktu widzenia problematyki niniejszego artykułu - wydaje się być propozycja Janusza Mariańskiego, który „wartość” określa jako „wszystko, co wiąże się z pozytywnymi emocjami, co skupia na sobie pragnienia i dążenia jednostek i czego one jako »rzeczy « cennej poszukują na co dzień"16. Maria Misztal natomiast wyróżnia trzy kategorie definicji wartości. Są to: 1) koncepcje psychologiczne (przedmiot wartości stanowi jednostka), 2) socjologiczne (przedmiot wartości stanowi grupa), 3) kulturowe (przedmiot wartości stanowi kultura) ${ }^{17}$. W mojej opinii macierzyństwo, ze względu na doniosłość, jaka jest w nie wpisana, implikacje indywidualne, grupowe oraz symbolikę kulturową, obejmuje wszystkie trzy powyższe obszary wartości.

Doświadczanie i oczekiwanie na macierzyństwo uwarunkowane jest szeregiem właściwości psychospołecznych, które mają wpływ na jego jakość. Ewa Włodarczyk wyróżnia następujące cechy w tym zakresie: postawy związane $\mathrm{z}$ macierzyństwem $\mathrm{w}$ rodzinie pochodzenia; model wyobrażenia własnego macierzyństwa w zakresie celu i zadań wychowawczych; związek emocjonal-

11 U. Tataj-Puzyna, Wartości w życiu człowieka - wartość macierzyństwa, „Kwartalnik Naukowy Fides et Ratio" 2014, nr 1, s. 53.

12 Macierzyństwo, w: Wielka Encyklopedia Prawa, red. E. Smoktunowicz, Prawo i Praktyka Gospodarcza, Białystok-Warszawa 2000, s. 432-433.

13 S. Pikus, Macierzyństwo w kodeksie rodzinnym i opiekuńczym, „Przegląd Prawno-Ekonomiczny” 2010, nr 13, s. 5-15.

${ }^{14}$ M. Pryszmont-Ciesielska, Macierzyństwo w perspektywie kobiet podejmujących aktywność naukowo-dydaktyczna - trzy autonarracje, „Edukacja Dorosłych” 2011, nr 2, s. 164.

15 D. Łamejko, Macierzyństwo jako wartość filozoficzna i moralna, „Etyka” 2003, t. 36, s. 193-208.

16 J. Mariański, Socjologia moralności, Wydawnictwo KUL, Lublin 2006, s. 341.

17 M. Misztal, Problematyka wartości w socjologii, PWN, Warszawa 1980, s. 14. 
ny matki z dzieckiem oraz fazy jego kształtowania się; fakt, czy ciąża stanowi zaskoczenie, czy też miała charakter zaplanowany ${ }^{18}$.

Wątkiem niezwykle istotnym - w kontekście podejmowanej w niniejszym tekście problematyki badań - jest samotne macierzyństwo. Bogusława Lachowska uwzględnia następujące uwarunkowania samotnego macierzyństwa: 1) urodzenie dziecka przez matkę niezamężną; 2) rozwód, separacja lub porzucenie kobiety przez męża; 3) śmierć współmałżonka ${ }^{19}$. Samotne macierzyństwo stanowi proces, w który wpisane mogą być cechy kryzysu, a to z kolei może implikować negatywne konsekwencje zarówno dla matki, jak i dziecka, ale również dla całej rodziny. Optymistyczne przesłanie w tym zakresie można jednak wskazać, odwołując się do badań Ewy Zawiszy, które wykazały, że w ocenie dorosłych dzieci samotne matki są życiowymi bohaterkami, w których funkcjonowanie wpisane są takie cechy, jak samodzielność, poświęcenie, dzielność i zaradność życiowa ${ }^{20}$. Autorka podkreśla, że „ważne jest, by zapewnić matce, która zostaje sama ze swym rodzicielstwem jak największą akceptację, która stanie się punktem wyjścia do budowania siły, jakiej potrzebuje do wykonania niezwykłego zadania - wychowywania dziecka"21. W związku z szeregiem wyzwań, jakie wpisane są w funkcjonowanie rodzin monoparentalnych, warte rozważenia są rozwiązania systemowe oparte m.in. na poradnictwie rodzinnym, prawnym i psychopedagogicznym, obejmujące procesy zarówno diagnostyczne, profilaktyczne, jak i terapetuczne.

\section{Założenia metodologiczne}

Celem badań była próba opisu i analizy tego, czym dla kobiet doświadczających bezdomności jest „szczęście”. Należy w tym miejscu zwrócić uwagę, że pojęcie szczęścia ma charakter niezwykle złożony i wieloaspektowy ${ }^{22}$.

${ }^{18}$ E. Włodarczyk, Młodzież wobec macierzyństwa i jego kulturowej kreacji, Wydawnictwo Naukowe Uniwersytetu Adama Mickiewicza, Poznań 2009, s. 65.

19 B. Lachowska, Samotne macierzyństwo, w: Oblicza macierzyństwa, red. D. Kornas-Biela, Redakcja Wydawnictw KUL, Lublin 1999, s. 282.

${ }^{20}$ E. Zawisza, Solomatki. Wspótczesne samotne macierzyństwo w lustrze net-przestrzeni, Wydawnictwo Naukowe Uniwersytetu Pedagogicznego im. Komisji Edukacji Narodowej w Krakowie, Kraków 2013, s. 97.

${ }^{21}$ Tamże, s. 26.

${ }^{22}$ Wielowymiarowość problematyki szczęścia implikuje różne ujęcia tego pojęcia. Maria Ossowska rozróżniła cztery znaczenia szczęścia: 1) los, 2) stan psychiczny, 3) bilans doświadczeń życiowych, 4) stereotypowe przyczyny szczęścia (np. spokój, cnota, harmonia wewnętrzna), M. Ossowska, Motywy postępowania. Z zagadnień psychologii moralności, Książka i Wiedza, Warszawa 2002, s. 41-42. Przez niektórych autorów pojęcie szczęścia utożsamiane jest z dobrostanem, zadowoleniem z życia lub jednym z wymiarów jakości życia. Zob. W. Tatarkiewicz, O szczęściu, PWN, Warszawa 1979, s. 3; R.L. Schalock, Three Decades of Quality of Life, „Focus on Autism and Other Developmental 
W związku z tym, że badania zaprezentowane w niniejszym artykule bazują ma paradygmacie jakościowym, nie uwzględniono przedzałożeń, ponieważ mogłyby one zniekształcić dążenia badawcze autorki. Problem badawczy obejmował następujące pytanie: w jaki sposób bezdomne kobiety definiują szczęście. Warto zaakcentować, że bezdomność to zjawisko, które, w perspektywie socjologicznej, najczęściej analizowane jest na podstawie paradygmatu ilościowego. W takie podejście badawcze wpisany jest szereg atutów przydatnych do celów demograficznych i systemowych, których implikacje stanowią istotną rolę w kontekście projektowania działań w zakresie polityki socjalnej. W ramach niniejszego przedsięwzięcia naukowego natomiast postanowiono zbadać bezdomne kobiety jako jednostki, które z subiektywnego punktu widzenia opisują i nadają znaczenie szczęściu. Ponadto trzeba zaznaczyć, że podjęta w tekście problematyka stanowi jeden z elementów szerzej zakrojonych badań nad bezdomnością kobiet. Z uwagi na oczywiste ograniczenia związane $\mathrm{z}$ objętością tekstu w niniejszym artykule zredukowano zakres materiału badawczego, uwzględniając tylko jedną z wyodrębnionych przez autorkę kategorii badawczych. W związku z uwzględnioną w badaniu metodą, którą było studium przypadku, materiał badawczy obejmował 5 wywiadów narracyjnych zrealizowanych wśród bezdomnych kobiet-mieszkanek schronisk w dwóch miastach wojewódzkich w Polsce. Techniką badawczą, jaką się posłużono, był wywiad narracyjny, stanowiący szczególną formę wywiadu swobodnego lub pogłębionego. Co istotne, specyfika takich wywiadów wiąże się ze zgodą na poruszenie tych zakresów tematycznych, które proponuje sam narrator. To z kolei jest związane z szerszym spektrum badanego zjawiska, pozwalając osobie badanej samej decydować, co chce powiedzieć i w jaki sposób. Krzysztof Konecki tłumaczy: „opowiadający jest najlepiej zorientowany w wiedzy o swojej biografii, dlatego też należy mu zostawić pełną swobodę w opowiadaniu swojej historii życia"23. Ze względu na dochowanie anonimowości imiona kobiet zredukowano do ich pierwszej litery. W przypadku dwóch kobiet imiona dublują

Disabilities" 2000, t. 15, nr 2, s. 116-127; B. Christoph, H. Noll, Subjective Well-Being in The European Union During the 90s, „Social Indicators Research” 2003, t. 64, nr 3, s. 521-546. Erick Allard natomiast zwraca uwagę, że pojęcie szczęścia ma charakter indywidualny, a zatem opisywane jest za pomocą subiektywnych wskaźników. Zob. E. Allard, Having, Loving, Being. An Alternative to the Swedish Model of Welfare Research, w: The Quality of Life, red. M.C. Nussbaum, A. Sen, Clarendon Press, Oxford 1993, s. 88-94. Inni autorzy zagadnienie szczęścia łączą z kategorią jakości życia: „jeśli przez szczęście rozumiemy poczucie radości i zadowolenia z życia, to jakość życia jest zdecydowanie szerszą kategorią. Natomiast gdy uwzględnimy bardziej szeroką definicję szczęścia jako życia spełniającego się, można znaleźć więcej podobieństw pomiędzy jakością życia a szczęściem. W obydwu przypadkach znaczenie ma wymiar aksjologiczny, sens życia, samorealizacja, wymiar jednostkowy oraz społeczny", T. Kanasz, Uwarunkowania szczęścia. Socjologiczna analiza wyobrażeń młodzieży akademickiej o szczęściu i udanym życiu. Wydawnictwo Akademii Pedagogiki Specjalnej, Warszawa 2015, s. 33.

${ }^{23} \mathrm{~K}$. Konecki, Studia z metodologii badań jakościowych. Teoria ugruntowana, Wydawnictwo Naukowe PWN, Warszawa 2005, s. 82. 
się, stąd oznaczenia „A” i „A.2”. Szczegółową charakterystykę cech społeczno-demograficznych badanych przedstawiają dane w tabeli 1.

Tabela 1. Charakterystyka badanych osób

\begin{tabular}{|c|c|c|c|c|c|c|c|c|}
\hline Lp. & Imię & Wiek & $\begin{array}{c}\text { Miejsce } \\
\text { urodzenia }\end{array}$ & $\begin{array}{l}\text { Wyksztal- } \\
\text { cenie }\end{array}$ & $\begin{array}{c}\text { Liczba } \\
\text { i wiek dzieci }\end{array}$ & $\begin{array}{l}\text { Czas prze- } \\
\text { bywania } \\
\text { w placówce }\end{array}$ & $\begin{array}{l}\text { Stan } \\
\text { cywilny }\end{array}$ & $\begin{array}{c}\text { Deklarowana } \\
\text { przyczyna } \\
\text { bezdomności }\end{array}$ \\
\hline 1. & M. & 21 & wieś & $\begin{array}{l}\text { gimna- } \\
\text { zjalne }\end{array}$ & $\begin{array}{c}1: \text { córka } \\
(13 \text { miesięcy) }\end{array}$ & rok & panna & $\begin{array}{c}\text { przemoc } \\
\text { w rodzinie }\end{array}$ \\
\hline 2. & A. 2 & 21 & wieś & $\begin{array}{l}\text { gimna- } \\
\text { zjalne }\end{array}$ & $\begin{array}{c}\text { 2: córka } \\
\text { (2 lata), córka } \\
\text { (3 lata) }\end{array}$ & 2 lata & panna & $\begin{array}{c}\text { przemoc } \\
\text { w rodzinie }\end{array}$ \\
\hline 3. & A. & 20 & $\begin{array}{l}\text { miasto do } \\
100 \text { tys. } \\
\text { mieszkań- } \\
\text { ców }\end{array}$ & $\begin{array}{l}\text { gimna- } \\
\text { zjalne }\end{array}$ & 1: syn (2 lata) & 2 lata & panna & $\begin{array}{c}\text { kłótnia } \\
\text { z partnerem }\end{array}$ \\
\hline 4. & P. & 39 & wieś & $\begin{array}{c}\text { średnie } \\
\text { technicz- } \\
\text { ne }\end{array}$ & $\begin{array}{l}\text { 8: syn (2 lata); } \\
\text { pozostałe dzie- } \\
\text { ci pełnoletnie, } \\
\text { nie mieszkają- } \\
\text { ce z badaną }\end{array}$ & 7 lat & $\begin{array}{l}\text { rozwie- } \\
\text { dziona }\end{array}$ & $\begin{array}{l}\text { alkoholizm } \\
\text { partnera }\end{array}$ \\
\hline 5. & K. & 27 & $\begin{array}{l}\text { miasto po- } \\
\text { wyżej } 300 \\
\text { tys. miesz- } \\
\text { kańców } \\
\end{array}$ & $\begin{array}{l}\text { podstawo- } \\
\text { we }\end{array}$ & $\begin{array}{l}\text { 2: syn (2 lata), } \\
\text { córka (14 mie- } \\
\text { sięcy) }\end{array}$ & 4 lata & $\begin{array}{l}\text { rozwie- } \\
\text { dziona }\end{array}$ & $\begin{array}{c}\text { „wyrzucenie” } \\
\text { z domu przez } \\
\text { matkę }\end{array}$ \\
\hline
\end{tabular}

Źródło: opracowanie własne.

\section{Wyniki badań własnych}

Prezentując wypowiedzi narratorek, należy wskazać, że poczucie szczęścia to wartość, którą wszystkie badane kobiety odnoszą do macierzyństwa i nadają mu wysoką rangę:

- Szczęście to jest oczywiście moje dziecko (M.);

- Największym szczęściem dla mnie to są moje dzieci: największy skarb na świecie (P.);

- W tym momencie moje dzieci są dla mnie szczęściem (A.2);

- To, że mam dzieci (K.);

- To, że zostałam matką (A.).

W narracjach bezdomnych kobiet pojawiają się egzemplifikacje tego, w jaki sposób określają one szczęście związane z posiadaniem dzieci:

- Jak byli mali, no malutcy: syn i córka i jakby zdjęcia wtedy porównać, to by pani powiedziała, że bliźniaki. Tak, wyglądają jak bliźniaki. A tak podobni są 
do siebie! Ona jak jest zmęczona, to też przyjdzie, położy się, przytuli, pójdzie spać. Ona, w porównaniu do niego, to aniołek. A mała taka grzeczna, jak widzi, że sprzątam, to zaraz mi szufelkę poda, ona ma swoją szufelkę, ale ona swoje za uszami też ma, zaczyna się nieraz: potrafi chwycić za szyję i go [brata - M. P.-B.] przewrócić na tapczan, taką ma siłę, dwulatek! Albo tutaj go ściśnie, pociągnie, na tapczan wywróci. (K.)

Wypowiedź M. również wskazuje na odczuwaną radość z macierzyństwa. Co więcej, fakt pojawienia się na świecie dziecka podniósł poziom poczucia odpowiedzialności kobiety, a także zmienił postrzeganie jej pozycji w świecie społecznym. Kobieta bowiem deklaruje, że dziecko stało się osobą, dzięki której jej tożsamość społeczna jest bogatsza: nie żyje bowiem tylko dla siebie, ale również pełni rolę mamy. Podkreśla przy tym, że to, co wpisuje się w macierzyństwo, stanowi dla niej wielką wartość i buduje poczucie szczęścia. W poniższej narracji kobieta podjęła również kwestię aborcji, którą proponował jej były partner, jednak ona wyraziła absolutny sprzeciw w tej kwestii:

- Jak ona np. przyjdzie do mnie potulić się. Jak razem zasypiamy i ona jest taka słodziutka. Chociaż wiadomo: też czasem ryczy. Ja w sumie młodo zostałam mamą, kiedyś nie chciałam, w sensie nie myślałam o tym w ogóle, ale jak się przydarzyło, to nawet były partner mówił, żeby przerwać, w sensie aborcji dokonać. Ja na to: nigdy. Nigdy bym tego nie zrobiła. Mimo, żeśmy nie planowali. On się może przestraszył czy coś. Teraz to ja jestem szczęśliwa, to zupełnie inne życie $\mathrm{z}$ dzieckiem. Nie jesteś już sama dla siebie, tylko masz odpowiedzialność. Nie tylko, że w sensie pampersa trzeba zmieniać, ale chodzi o to, że już to nie tylko twoje życie. Wie pani, że ja kiedyś lubiłam na dyskoteki chodzić tam u mnie, tam właśnie poznałam tego partnera, a teraz to już w ogóle nie chcę, wolę z małą być. (M.)

Treści, jakie pojawiają się w narracji A., także świadczą o odpowiedzialności za swoje dzieci, lecz kobieta wskazuje również na zmianę postrzegania własnego życia w związku z pojawieniem się potomstwa:

- Jest dla mnie wszystkim, całym światem... że kiedyś po prostu jak miałam problemy, czułam się samotna, no to tak myślałam nieraz nawet o samobójstwie, a odkąd się małe pojawiły, to wiem, że bym tego nie zrobiła, no bo bym ich nie zostawiła. (A.)

Wypowiedź A.2 wskazuje na troskę i poczucie szczęścia, jakie wynikają z codziennego doświadczania macierzyństwa i obowiązków mu towarzyszących:

- Na przykład jak moja córka zje obiad, takie błahostki, naprawdę. Wczoraj byłam taka szczęśliwa, jak ona zjadła, bo ona naprawdę mało je, często choruje, chudnie i ja bardzo np. na to zwracam uwagę. Albo np. takie zabawy z dziećmi, spędzanie czasu z nimi, a czasem szczerze - jak mogę się wyspać. (A.2)

Narracja P. natomiast, na tle pozostałych, jest o tyle unikatowa, że komunikuje poczucie lęku o swoje dziecko w kontekście jego problemów medycznych. 
Kobieta martwi się o stan zdrowia swojego synka, ale jednocześnie towarzyszy jej nadzieja, że sfera zdrowotna dziecka ulegnie poprawie:

- Najgorzej to ja się nie cieszę, tylko martwię jego zdrowiem, bo on ma problemy z nerkami. Tu z nami starsza córka jest, ale ona już dużo samodzielna jest, a mały ciągle coś. Ja mam wrażenie, mam nadzieję, że będzie dobrze z tymi nerkami, bo to różnie pani doktor mówi, jak jeździmy na kontrolę. Ja o sobie już teraz nie myślę, bo syn jest najważniejszy, ale właśnie się martwię tymi złogami w nerkach. Po nim tak nie widać mocno, tak normalnie, jak się patrzy. Wie pani, po buźce czy coś. Normalnie wygląda. Trochę się martwię mocno, ale teraz ta medycyna to rozwinięta jest i ja liczę, że to mu się poprawi, te złogi czy... nie pamiętam jak to się nazywało. A ja kocham go nad życie, moje maleństwo, ja liczę, że będzie dobrze. (P.)

\section{Analiza badań własnych na tle porównawczym}

Nie sposób nie podkreślić faktu, że w obrębie dostępnej literatury przedmiotu zagadnienie szczęścia związanego z macierzyństwem bezdomnych kobiet nie jest prezentowane ani analizowane. Konstatacja ta jest o tyle istotna, że z przywołanych narracji bezdomnych kobiet wynika, iż poczucie szczęścia warunkowane jest macierzyństwem. Dla wszystkich badanych fakt posiadania dziecka lub dzieci oraz towarzyszące temu role, obowiązki i aktywności stanowią najwyższą wartość. Co istotne, w wypowiedziach bezdomnych kobiet nie pojawiły się żadne inne aspekty związane $z$ definiowaniem przez nich szczęścia.

Warto zaznaczyć, że poczucie szczęścia bezdomnych kobiet, które jest konsekwencją doświadczania macierzyństwa, wpisuje się w ogólną charakterystykę Polaków w tym zakresie. Przykład może stanowić Diagnoza Społeczna 2015. Warunki i jakość życia Polaków autorstwa Janusza Czapińskiego i Tomasza Panka ${ }^{24}$, w której posiadanie dziecka lokuje się jako drugi (poniżej zdrowia) wskaźnik odczuwanego szczęścia, ponadto trend ten jest niezmienny na przestrzeni ostatniej dekady.

W tym miejscu warto przytoczyć wyniki badań zagranicznych dotyczące poczucia szczęścia osób bezdomnych. Badania hiszpańskie w tym temacie dowiodły, że połowa bezdomnych obywateli Hiszpanii, którzy wzięli udział w badaniach, zadeklarowała, że jest szczęśliwa ${ }^{25}$. W badaniach Adeline Nyamathi i współpracowników z zakresu zależności między jakością relacji małżeńskich a poczuciem dobrostanu u bezdomnych kobiet okazało się, że kobiety, które

${ }^{24}$ Diagnoza społeczna 2015. Warunki i jakość życia Polaków, red. J. Czapiński, T. Panek, Rada Monitoringu Społecznego, Warszawa 2015, s. 230.

25 S. Panadero, A.I. Guillén, J.J. Vázquez, Happiness on the Street: Overall Happiness Among Homeless People in Spain, „American Journal of Orthopsychiatry” 2015, t. 85, nr 4, s. 324-330. 
funkcjonują w związkach bez przemocy, charakteryzują się lepszym samopoczuciem psychicznym i wyższym poczuciem własnej wartości niż kobiety samotne oraz te, które są w związkach przemocowych ${ }^{26}$. Natomiast badania holenderskie ${ }^{27}$ wykazały, iż bezpośredni predyktor dobrostanu bezdomnych mieszkańców schronisk stanowi możliwość uczestnictwa w grupach edukacyjnych, organizowanych w ośrodku. Zajęcia z zakresu szeroko rozumianej edukacji, rekreacji oraz aktywizacji zawodowej przyczyniły się do poprawy samopoczucia zarówno psychicznego, jak i fizycznego. Badane osoby podkreśliły, że poprzez udział w oferowanych przez schronisko aktywnościach wzmocniły swoją sieć wsparcia społecznego, a także deklarowały podwyższenie samooceny. Na uwagę zasługują również badania Lindy Grabbe i współpracowników przeprowadzone na terenie schroniska dla bezdomnych kobiet, których cel stanowił wskazanie zależności między podejmowaniem aktywności pod postacią zajęć ogrodniczych a poczuciem dobrostanu psychicznego. Oferta schroniska obejmowała możliwość założenia i pielęgnacji ogródka warzywnego, a także możliwość spożywania owoców tego zajęcia. Wyniki badań wykazały, że zajmowanie się ogrodnictwem pozytywnie wpłynęło na obniżenie negatywnych ruminacji bezdomnych kobiet, przyczyniło się do obniżenia odczuwanego przez nie stresu, a także stanowiło obszar reintegracji społecznej i pole do samorealizacji ${ }^{28}$. Najnowsze, znane autorce badania nad dobrostanem bezdomnych kobiet, w obszarze których znalazło się określenie związku między poziomem dobrostanu a aktywnością społeczną i fizyczną, dowiodły, że zajęcia takie jak wycieczki piesze, łucznictwo oraz wspinaczka górska przyczyniły się do polepszenia samopoczucia społecznego i interpersonalnego (social and interpersonal well-being improvment ${ }^{29}$.

\section{Wnioski}

Kluczowy wniosek, który wynika z przeprowadzonych badań, można skonkludować następująco: dla bezdomnych kobiet macierzyństwo stanowi najwyższy wymiar odczuwanego szczęścia. Należy podkreślić, że narratorki, mając

26 A. Nyamathi, S. Wenzel, C. Keenan, Associations Between Homeless Women's Intimate Relationships and their Health and Well-Being, „Research in Nursing \& Health” 1999, t. 22, nr 6, s. 486-495.

27 M. Rutenfrans-Stupar, T. van Regenmortel, R. Schalk, How to Enhance Social Participation and Well-Being in (Formerly) Homeless Clients: A Structural Equation Modelling Approach, „Social Indicators Research" 2019, t. 145, nr 1, s. 329-348.

28 L. Grabbe, J. Ball, A. Goldstein, Gardening for the Mental Well-Being of Homeless Women, „Journal Off Holistic Nursing” 2013, t. 31, nr 4, s. 258-266.

29 R. Gomez, Ch. Norton, J. Courtney i in., Perceptions of Learned Helplessness Among Emerging Adults Aging Out of Foster Care, „Child and Adolescent Social Work Journal” 2015, t. 32, nr 6, s. 507-516. 
pełną swobodę wypowiedzi, poza aspektem posiadania dziecka lub dzieci nie wskazywały na żaden inny obszar, który łączy się z odczuwanym przez nie szczęściem. Pełnienie ról macierzyńskich, pielęgnacja i opieka nad swoimi dziećmi stanowią aktywności bezdomnych kobiet, tworzące tę przestrzeń ich życia, która sprawia, że są szczęśliwe.

Wyniki badań mogą obejmować również aspekt aplikacyjny. Biorąc bowiem pod uwagę, że macierzyństwo stanowi najważniejszy, a wręcz jedyny wymiar poczucia szczęścia bezdomnych kobiet, warto w praktycznych działaniach pomocowych skierowanych wobec bezdomnych matek uwzględnić obszar dotyczący projektów z zakresu podwyższenia jakości kompetencji rodzicielskich. Fakt, że kobiety wychowują samotnie swoje dzieci w schroniskach dla osób bezdomnych, niesie bowiem ze sobą pewne zagrożenia $\mathrm{w}$ zakresie poprawnej socjalizacji dzieci. Zasadne byłoby zatem wdrożenie takich działań, które pozwoliłyby bezdomnym matkom lepiej radzić sobie z codziennymi obowiązkami macierzyńskimi, zarówno w kontekście praktycznym (przykładowo w zakresie opieki, higieny i pielęgnacji swoich dzieci), jak również w wymiarze emocjonalnym (przykładowo w zakresie radzenia sobie ze stresem). Powyższe rekomendacje mogłyby pozytywnie wpłynąć na proces wychowawczy dzieci, a jednocześnie na lepsze funkcjonowanie psychospołeczne ich matek. Kompilacja powyższych właściwości w konsekwencji mogłaby przynieść podwyższenie jakości życia bezdomnych, monoparentalnych rodzin.

Na koniec wypada skonstatować, że zaprezentowane badania i ich analiza stanowią jedynie skromny wycinek zagadnień omawianej problematyki, który może być punktem wyjścia do dalszych, szerszych analiz w tym zakresie. Obraz tego, jaką wartość dla bezdomnych kobiet stanowi macierzyństwo, niewątpliwie wymaga uzupełnień, a także pogłębionych badań naukowych.

\section{Bibliografia}

Allardt E., Having, Loving, Being. An Alternative to the Swedish Model of Welfare Research, w: The Quality of Life, red. M.C. Nussbaum, A. Sen, Clarendon Press, Oxford 1993, s. 88-94, DOI: 10.1093/0198287976.001.0001.

Arangua L., Andersen R., Gelberg L., The Health Circumstances of Homeless Women in the United States, "International Journal of Mental Health" 2005, t. 34, nr 2, s. 62-92.

Azim A., MacGillivray, Heise D., Mothering in the Margin: a Narrative Inquiry of Women with Children in a Homeless Shelter, ,Journal of Social Distress and The Homeless" 2019, t. 28, nr 1, s. 34-43, DOI: 10.1080/10530789.2018.1548091.

Bielecka-Prus J., Sytuacja życiowa osób bezdomnych, w: Społeczne i instytucjonalne aspekty bezdomności na Lubelszczyźnie, red. J. Bielecka-Prus, P. Rydzewski, R. Maciejewska, Wydawnictwo WSPA, Lublin 2011, s. 11-30.

Christoph B., Noll H., Subjective Well-Being in The European Union During the 90s, ,, Social Indicators Research" 2003, t. 64, nr 3, s. 521-546, DOI: 10.1023/A:1025983431755. 
David D., Gelberg L., Suchman N.E., Implications of Homelessness for Parenting Young Children: a Preliminary Review from a Developmental Attachment Perspective, "Infant Mental Health Journal" 2012, t. 33, nr 1, s. 1-9, DOI: 10.1002/imhj.20333.

Dębski M., Sytuacja społeczna bezdomnych kobiet w województwie pomorskim, w: Forum. O bezdomności bez lęku, red. $Ł$. Browarczyk, Pomorskie Forum na Rzecz Wychodzenia z Bezdomności, Gdańsk 2008, s. 11-106.

Dębski M., Michalska A., Podręcznik streetworkera bezdomności, Pomorskie Forum Na Rzecz Wychodzenia z Bezdomności, Gdańsk 2012.

Diagnoza społeczna 2015. Warunki i jakość życia Polaków, red. J. Czapiński, T. Panek, Rada Monitoringu Społecznego, Warszawa 2015.

Gomez R., Norton Ch., Courtney J. i in., Perceptions of Learned Helplessness Among Emerging Adults Aging Out of Foster Care ,"Child and Adolescent Social Work Journal" 2015, t. 32, nr 6, s. 507-516, DOI: 10.1007/s10560-015-0389-1.

Grabbe L., Ball J., Goldstein A., Gardening for the Mental Well-Being of Homeless Women, „Journal of Holistic Nursing" 2013, t. 31, nr 4, s. 258-266, DOI: 10.1177/0898010113488244.

Hanrahan P., McCoy M., Cloninger L. i in., The Mothers' Project for Homeless Mothers with Mental IIInesses and Their Children: A Pilot Study, ,"Psychiatric Rehabilitation Journal" 2005, t. 28, nr 3, s. 291-294.

Kanasz T., Uwarunkowania szczęścia. Socjologiczna analiza wyobrażeń młodzieży akademickiej o szczęściu i udanym życiu, Wydawnictwo Akademii Pedagogiki Specjalnej, Warszawa 2015.

Kaźmierczak-Kałużna I., Bezdomność jako forma wykluczenia społecznego w świetle wybranych aktów prawnych oraz dokumentów strategicznych i programowych, "Opuscula Sociologica” 2015, nr 2, s. 19-36, DOI: 10.18276/o s.2015.2-02.

Konecki K., Studia z metodologii badań jakościowych. Teoria ugruntowana, Wydawnictwo Naukowe PWN, Warszawa 2005.

Kubicka H., Bezdomność rodzin samotnych matek. Społeczno-wychowawcze aspekty zjawiska, Wydawnictwo Uniwersytetu Łódzkiego, Łódź 2005.

Lachowska B., Samotne macierzyństwo, w: Oblicza macierzyństwa, red. D. Kornas-Biela, Redakcja Wydawnictw KUL, Lublin 1999, s. 280-287.

Łamejko D., Macierzyństwo jako wartość filozoficzna i moralna „Etyka” 2003, t. 36, s. 193-208.

Maciejewska R., Bielecka-Prus J., Problemy w funkcjonowaniu instytucji działających na rzecz pomocy osobom bezdomnym, w: Społeczne i instytucjonalne aspekty bezdomności na Lubelszczyźnie, red. J. Bielecka-Prus, P. Rydzewski, R. Maciejewska, Wydawnictwo WSPA, Lublin 2011, s. 201-229.

Macierzyństwo, w: Wielka Encyklopedia Prawa, red. E. Smoktunowicz, Prawo i Praktyka Gospodarcza, Białystok-Warszawa 2000, s. 432-433.

Mariański J., Socjologia moralności, Wydawnictwo KUL, Lublin 2006.

Mikołajczyk M., Rodziny bezdomnych matek. Charakterystyka i działania pomocowe, Wydawnictwo Akademii Pedagogiki Specjalnej, Warszawa 2018.

Misztal M., Problematyka wartości w socjologii, PWN, Warszawa 1980.

Nyamathi A., Wenzel S., Keenan C. i in., Associations Between Homeless Women's Intimate Relationships and Their Health and Well-Being, "Research in Nursing \& Health" 1999, t. 22, nr 6, s. 486-495, DOI: 10.1002/(SICI)1098-240X(199912)22:6<486::AID-NUR6>3.0.CO;2-6.

Ossowska M., Motywy postępowania. Z zagadnień psychologii moralności, Książka i Wiedza, Warszawa 2002.

Panadero S., Guillén A.I., Vázquez J.J., Happiness on the Street: Overall Happiness Among Homeless People in Spain, "American Journal of Orthopsychiatry” 2015, t. 85, nr 4, s. 324-330, DOI: 10.1037/ort0000080.

Phipps M., Dalton L., Maxwell H. i in., Women and Homelessness, a Complex Multidimensional Issue: Findings From a Scoping Review, ,Journal of Social Distress and The Homeless" 2019, t. 28, nr 1, s. 1-13, DOI: 10.1080/10530789.2018.1534427. 
Piechowicz M., Specyfika funkcjonowania bezdomnych rodzin na przykładzie bezdomnych kobiet z dziećmi w Gdańsku, w: Rodzina wobec problemów i wyzwań współczesności. W poszukiwaniu rozwiq̨zań, red. B. Chrostowska, M. Dymowska, M. Zmysłowska, t. 2, Wydawnictwo Uniwersytetu Warmińsko-Mazurskiego w Olsztynie, Olsztyn 2015, s. 171-180.

Piekut-Brodzka D., O bezdomnych i bezdomności. Aspekty fenomenologiczne, etiologiczne, terapeutyczne, Chrześcijańska Akademia Teologiczna, Warszawa 2000.

Pikus S., Macierzyństwo w kodeksie rodzinnym i opiekuńczym, „Przegląd Prawno-Ekonomiczny” 2010, nr 13, s. 5-15.

Pryszmont-Ciesielska M., Macierzyństwo w perspektywie kobiet podejmujących aktywność naukowo-dydaktyczna - trzy autonarracje, „Edukacja Dorosłych” 2011, nr 2, s. 163-178.

Przymeński A., Bezdomność jako kwestia społeczna w Polsce współczesnej, Wydawnictwo Akademii Ekonomicznej w Poznaniu, Poznań 2001.

Roze M., ven der Wearden J., Melchior M. i in., Factors Associated with Depression Among Homeless Mothers. Results of the ENFAMS Survey, "Journal od Affective Disorders" 2018, t. 229, s. 314-321, DOI: 10.1016/j.jad.2017.12.053.

Rutenfrans-Stupar M., van Regenmortel T., Schalk R., How to Enhance Social Participation and Well-Being in (Formerly) Homeless Clients: A Structural Equation Modelling Approach, "Social Indicators Research" 2019, t. 145, nr 1, s. 329-348, DOI: 10.1007/s11205-019-02099-8.

Schalock R.L., Three Decades of Quality of Life, „Focus on Autism and Other Developmental Disabilities" 2000, t. 15, nr 2, s. 116-127, DOI: 10.1177/108835760001500207.

Sucharska-Daraż A., Kryzys w wartościowaniu a postawy życiowe bezdomnych kobiet, w: Osoby bezdomne. Psychologiczne aspekty ich funkcjonowania, red. M.A. Basińska, Fundacja Salvus, Bydgoszcz 2014, s. 191-221.

Swick K., Responding to the Voices of Homeless Preschool Children and Their Families, „Early Childhood Education Journal" 2010, t. 38, nr 4, s. 299-304, DOI: 10.1007/s10643-010-0404-2.

Szluz B., Świat społeczny bezdomnych kobiet, Bonus Liber, Warszawa 2010.

Tataj-Puzyna U., Wartości w życiu człowieka - wartość macierzyństwa, „Kwartalnik Naukowy Fides et Ratio" 2014, nr 1, s. 50-56.

Tatarkiewicz W., O szczęściu, PWN, Warszawa 1979.

Tyl M., Dysfunkcjonalność rodziny a bezdomność, „Praca Socjalna” 2005, nr 1, s. 46-59.

Upshur C., Jenkins D., Weinreb L. i in., Prevalence and Predictors of Substance Use Disorders Among Homeless Women Seeking Primary Care: An 11 Site Survey: Prevalence and Predictors of Homeless Women's Alcohol and Drug use Disorders, "The American Journal on Addictions"2017, t. 26, nr 7, s. $680-688$, DOI: 10.1111/ajad.12582.

Whitbeck L., Armenta B., Welch-Lazoritz M., Borderline Personality Disorder and Axis I Psychiatric and Substance Use Disorders Among Women Experiencing Homelessness in Three US Cities, "Social Psychiatry and Psychiatric Epidemiology" 2015, t. 50, nr 8, s. 1285-1291, DOI: 10.1007/ s00127-015-1026-1.

Włodarczyk E., Młodzież wobec macierzyństwa i jego kulturowej kreacji, Wydawnictwo Naukowe Uniwersytetu Adama Mickiewicza, Poznań 2009.

Zawisza E., Solomatki. Współczesne samotne macierzyństwo w lustrze net-przestrzeni, Wydawnictwo Naukowe Uniwersytetu Pedagogicznego im. Komisji Edukacji Narodowej w Krakowie, Kraków 2013.

Żmuda B., Pułapka szczęścia współczesnego człowieka, „Logos i Ethos” 2016, t. 40, nr 1, s. 41-51, DOI: 10.15633/lie.1697. 


\section{Streszczenie}

Niniejszy artykuł stanowi próbę opisu i analizy wartości macierzyństwa jako aspektu poczucia szczęścia kobiet doświadczających bezdomności. Metodą, jaką posłużono się w badaniu, było studium przypadku. Analizie poddany został materiał empiryczny stanowiący efekt pięciu wywiadów narracyjnych. W tekście wyodrębniono kilka obszarów. Pierwsze dwa mają charakter wprowadzający - obejmują bowiem teoretyczne podstawy badań (pojęcie bezdomności kobiet oraz pojęcie macierzyństwa). Kolejny element artykułu dotyczy założeń metodologicznych. Czwarta część tekstu stanowi prezentację wyników badań własnych; ostatnia natomiast uwzględnia analizę i dyskusję badań wraz z odniesieniem do dotychczasowych doniesień badawczych w omawianym zakresie, a także wnioski aplikacyjne.

Słowa kluczowe: wartości, poczucie szczęścia, dobrostan, bezdomne kobiety, macierzyństwo

\section{The Value of Motherhood as a Dimension of the Sense of Happiness Experienced by Homeless Women}

\section{Summary}

This article is an attempt to describe and analyse the value of motherhood as a dimension of the sense of happiness reported by women experiencing homelessness. The research relies on case study methodology. Analysed is empirical material from five narrative interviews. The text has a number of structural components. The first two are introductory as they cover the theoretical foundations of the research (the concept of homelessness of women and the concept of motherhood). These are followed by methodological assumptions. The fourth part presents research results, while the final part contains an analysis and discussion with reference to previous relevant research reports. The article ends with a handful of practical conclusions.

Key words: values, sense of happiness, well-being, homeless women, motherhood 